\title{
A DITADURA URUGUAIA NA FICÇÃO DE MARIO BENEDETTI
}

\author{
Irineu Pacheco Paes Barreto ${ }^{1}$
}

Resumo: O objetivo deste artigo é refletir sobre as representações da ditadura uruguaia (1985-1973) presentes na ficção de Mario Benedetti (1920-2009). Para tanto, analisamos o livro de contos Con y sin nostalgia (1977) e a novela Primavera com uma esquina rota (1982). O trabalho está dividido em quatro seções. Abordamos, inicialmente, o estilo realista de Benedetti. A seguir, apresentamos uma síntese histórica do período em que o autor viveu no exílio, que coincide, na primeira etapa, com o auge da repressão política no Uruguai, e, numa segunda fase, corresponde ao processo de abertura do regime militar. Dedicamos as duas últimas seções à apreciação das obras ficcionais citadas.

Palavras-chave: Uruguai, ditadura, ficção, Mario Benedetti

Abstract: The objective of this paper is to discuss the representations of the Uruguayan dictatorship (1973-1985) presented in Mario Benedetti's fiction. For this purpose, we analyze the tales of the storybook Con y sin nostalgia (1977) and the novel Primavera con una esquina rota (1982). The work is divided into four sections. Initially we approach Benedetti's realistic style. Then we present an overview of the historical period the author lived in exile, which coincides, in the first stage, with the height of political repression in Uruguay, and in a second stage it corresponds to the opening process of the military regime. The last two sections are dedicated to the appreciation of the fictional texts cited.

Keywords: Uruguay, dictatorship, fiction, Mario Benedetti

${ }^{1}$ Ministério das Relações Exteriores - Itamaraty. E-mail: neubarreto@bol.com.br 


\section{INTRODUÇÃO: MARIO BENEDETTI E A REPRESENTAÇÃO}

\section{DA REALIDADE URUGUAIA}

Mais de meio século após Benedetti haver publicado seu primeiro livro de contos, a crítica Carmen Alemany Bay podia afirmar que o autor "é, sem dúvida, um dos escritores uruguaios mais lidos no âmbito hispano-americano, no espanhol e em numerosos países europeus" (Bay,2000, p.11).

Ela atribui o sucesso de Benedetti à sua capacidade de estabelecer uma "comunicação efetiva" com seu público, graças ao seu trabalho de conversão da "realidade no eixo de sua obra".

Em 2007, dois anos antes da morte de Benedetti, o jornalista Leonardo Haberkorn, que entrevistou o escritor por diversas vezes, mostrava-se impressionado com o fato de que o autor - que não vendera nenhum exemplar de seus sete primeiro livros - naquele ano vendia "tantos livros que não era capaz de contar" (Haberkorn, 2011, p.153). Mas alguns números eram bem conhecidos e o jornalista os colocou em evidência: 91 livros publicados, somando 1266 edições; traduzido a mais de 30 idiomas... Êxito que teve início com a publicação de Poemas de la oficina (1956), de "linha clara, simples e cotidiana" (Haberkorn, 2011, p.153) que agradou o público. O discurso do escritor, a partir daí, passa a ser dominado pela "lírica coloquial" (Rein, 1996, p.159).

O coloquialismo foi uma das marcas do estilo neorrealista da geração de escritores à qual pertence Benedetti, a chamada "geração crítica, geração de 45 ou geração de Marcha" (Achugar, 2004, p.221). Um grupo de escritores que se voltou contra a "imagem acrítica, feliz e bonachona" (Achugar, 2004, p.221) da sociedade uruguaia que atribuíam às obras da literatura nacional então em voga.

Desde seus primeiros livros de contos e de poemas, Benedetti, seguindo alguns princípios do realismo, representa "o comportamento da classe média, em particular, os seus aspectos mais negativos" (Rein, 1996, p.151). Trata-se, em geral, de uma "visão amarga da classe média uruguaia, encerrada em suas ambições e também em suas frustrações, limitada em suas ilusões e perspectivas de futuro" (Lago apud Rein, 1996, p.165).

Mas ao contrário do que prega o cânone do realismo clássico, Benedetti optou pela narrativa em primeira pessoa na parte mais significativa da sua ficção. Utilizando uma linguagem simples e clara, evitou a contradição entre a "atenção ao banal e a impressão do artifício mais deliberado" (Valéry, 2010, p.62), característica do realismo do século XIX, exemplificado por Flaubert em Madame Bovary. O autor uruguaio pertence a uma corrente de escritores realistas que não se aprofundaram "na análise das causas sociais dos acontecimentos observados, interessando-se pelo reflexo dos mesmos na consciência dos personagens literários e suas consequências na atitude, na vida familiar e amorosa e no ambiente cultural do homem do século XX” (Greiner-Mai, 2006, p.302). Esses aspectos estilísticos, que estão associados às convicções ideológicas de Benedetti, sobretudo durante o período ditatorial vivido pela sociedade uruguaia (1973-1985), foram objeto do menosprezo de muitos críticos, que desqualificam sua obra como "superficial" e repleta de "lugares comuns" (Haberkorn, 2011, p.155).

Já para os seus admiradores, a obra de Benedetti é "radicalmente atual" em função da "indagação sobre a realidade social, seu espírito combativo e perseverante" e por "seu 
interesse pela justiça social” (Bay, 2000, p.12). É razoável supor que parte, ou grande parte, do sucesso de Benedetti junto ao público decorra dessa imagem do autor como intelectual engajado, primeiro em favor de uma revolução de esquerda, depois contra a ditadura. Essa é a origem, também, do menoscabo de certos críticos.

A ficção de Benedetti,é produto tanto de princípios literários quanto de convicções ideológicas e de representações sociais. Do nosso ponto de vista, o eixo de sua obra não é a realidade, mas sim representações do real construídas sob a forma de contos e novelas. A distinção é algo simples de entender, mas difícil de captar para quem lê as ficções de Benedetti segundo os dogmas do realismo direto ou ingênuo, que tende a ver nos relatos realistas uma descrição de "como as coisas são realmente". A perspectiva aqui adotada é a de que a ficção nos apresenta os conceitos e representações do escritor sobre a realidade. É um discurso particular sobre "o que é" e "o como deveria ser".

Ao longo da ficção de Benedetti surgem personagens sob a forma de empregados de escritório, domésticas, jornalistas, policiais, estudantes, empresários, políticos, militantes de esquerda, presos políticos, torturadores, exilados... Nessa obra, a experiência da tortura, que o escritor felizmente jamais sofreu, não é menos "verdadeira" que a descrição do trabalho de contador, que Benedetti exerceu durante anos e anos. Porque a produção de situações e de criaturas verossímeis e comovedoras é fruto da arte do narrador, não da vida do artista, pelo menos não diretamente. E é produto, também, das crenças do autor, sejam elas de natureza religiosa, política, filosófica, etc.

Nesse sentido, a ficção benedettiana que abordaremos neste artigo permite que acompanhemos, especificamente, a evolução temática e discursiva de Benedetti durante anos em que o Uruguai viveu sob uma ditadura “cívico-militar" (1973-1985). Trata-se de uma excelente oportunidade de comparar ficção e história para tentar obter uma visão global de um período tão complexo da sociedade uruguaia. A ficção, por um lado, revelando "os apetites e as fantasias", preenchendo "esse espaço entre a vida real e os desejos" (Vargas Llosa, 2004, p.21); a história, por sua vez, explicando as origens dos conflitos políticos e sociais que criam e/ou exacerbam as contradições entre a vida e o sonho, entre os seres humanos e os "fantasmas, nos quais esses seres se transformam para romper as barreiras que os limitam e os frustram" (Vargas Llosa, 2004, p.22).

\section{O EXÍLIO DE BENEDETTI DURANTE A DITADURA}

O profundo engajamento político de esquerda de Mario Benedetti, suas críticas sistemáticas ao Governo, seus vínculos com o regime cubano e seu envolvimento com o Movimento de Libertação Nacional-Tupamaros (MLN-T), grupo guerrilheiro que atuou no Uruguai durante aos anos 1960, obrigaram o escritor a abandonar o país poucos meses depois do golpe de Estado que no dia 27 de junho de 1973 dissolveu o Parlamento.

Na primavera de 1973, após a intervenção da ditadura na Universidade, Benedetti decidiu seguir a recomendação dos amigos e fugir de Montevidéu para Buenos Aires. O escritor tinha 53 anos, estava "sem emprego, sem dinheiro e com o passaporte prestes a vencer" (Campanella, 2008, p.147). Ele ainda retornará a Montevidéu no dia 31 de dezembro 
daquele ano, convocado para prestar esclarecimentos sobre sua ligação com um suposto guerrilheiro. Liberado após o interrogatório,retornou à capital argentina no dia seguinte.

No começo, Benedetti hospedou-se na casa de amigos e trabalhou para pequenas editoras. Em seguida, alugou um apartamento. Voltou a escrever para periódicos, uma fase que logo seria interrompida pela caótica situação política argentina, marcada pelo conflito interno do peronismo e pela ação do grupo paramilitar e terrorista de extrema direita "Alianza Anticomunista Argentina”, conhecido como “Triple A”. Este grupo foi responsável pelos desaparecimentos e assassinatos de artistas, intelectuais, guerrilheiros, políticos de esquerda, estudantes e sindicalistas. Em seu período em Buenos Aires, Benedetti, assim como vários outros intelectuais de esquerda, correu o risco de cair nas mãos da Triple A. Mesmo assim, permaneceu na Argentina até fevereiro de 1975, para ficar o mais próximo possível de Montevidéu, da esposa, da família e dos companheiros que, em quantidade cada vez maior, cruzavam o rio para escapar da ditadura.

$\mathrm{O}$ autor dedica-se, entre outros trabalhos, a escrever um roteiro de um filme com base em alguns de seus contos, à sua parceria com o músico argentino Alberto Favero (com o qual já colaborava desde 1972), antes deste partir para seu exílio no México. Entre os vários exilados uruguaios com os quais mantém relações, destacava-se o político Zelmar Michelini, quem, em março de 1974, denunciou perante o Tribunal Russel, em Roma, as violações de direitos humanos cometidas pela ditadura uruguaia. Benedetti e Michelini "durante meses se encontraram várias vezes por semana para comentar os acontecimentos da política uruguaia ou simplesmente para comer em um pequeno restaurante da rua Maipú e falar de livros, do "boom" latinoamericano, de Onetti" (Campanella, 2008, p.158). No dia 18 de maio de 1976, quando Benedetti já se encontrava exilado em Cuba, Michelini foi sequestrado em Buenos Aires, juntamente com o ex-deputado do Partido Nacional, Hector Gutiérrez Ruiz e mais dois militantes do Movimento de Libertação Nacional (MLN-Tupamaros), Rosario Barredo e William Whitelaw. Os quatro foram assassinados e seus corpos encontrados quatro dias depois na capital argentina (Martínez, 2008, p.34).

No Uruguai, 1974 é o ano da "consolidação ditatorial" (Caetano, Rilla, 2011, p.31). A "linha dura" dentro do Exército estabelece firmemente sua hegemonia. O Governo aprova a Lei Orgânica Militar que, entre outras medidas, "define o conceito de segurança nacional" (Martínez, 2008, p.34). A repressão contra os militantes e organizações de esquerda se intensifica. Aumenta o número de presos políticos, ao mesmo tempo em que "se deterioram, de forma geral, as condições de reclusão" (Caetano, Rilla, 2011, p. 32). O lema da campanha governamental lançada naquele ano contra os "inimigos da nação" é "um país sem marxismo se constrói com fé” (Martínez, 2008, p.34). A ditadura impõe pautas para a imprensa e proíbe o jornal de oposição "Ahora" e o célebre semanário "Marcha", entre outros. Jornalistas e intelectuais de destaque são presos e submetidos à justiça militar. Em junho, a "Organização das Nações Unidas divulga um relatório elaborado pela Anistia Internacional e pela Comissão Internacional de Juristas" que acusa a justiça militar uruguaia de haver sistematizado o emprego da tortura (Martínez, 2008, p.37).

Benedetti e os outros compatriotas exilados em Buenos Aires vivem em um ambiente de terror, correndo o risco de serem sequestrados e mortos. É o que aconteceu, por exemplo, no dia 13 de setembro de 1974 com três uruguaios - Daniel Banfi, Guillermo Jabif e Luis 
Latrónica. Seus corpos foram encontrados um mês depois "baleados, cobertos de cal e com sinais de tortura" (Martínez, 2008, p.40). No dia 8 de novembro, cinco militantes do MLN foram também sequestrados na capital argentina. Seus corpos foram encontrados no dia 20 de dezembro, em uma localidade perto de Montevidéu. O líder do Partido Nacional, Wilson Ferreira Aldunate, denunciou na época que as execuções ocorreram em represália pelo assassinato do Coronel Ramón Trabal, adido militar da Embaixada do Uruguai em Paris, ação que as Forças Armadas atribuíram ao MLN.

É nesse contexto que Benedetti descobre que seu nome consta de uma lista de condenados à morte pela "Triple A" e dispõe de 48 horas para deixar a Argentina. Em sua novela "Primavera con una esquina rota", de 1982, Benedetti intercala os capítulos de ficção com textos autobiográficos. No livro, o final do exílio em Buenos Aires é relembrado como um tempo assustador: "em janeiro de 1975 era comum aparecer dez ou doze cadáveres diariamente nos depósitos de lixo portenhos" (Benedetti, 2011, p.20).

O escritor foge para Lima, sendo lá acolhido por um amigo argentino. Durante o exílio no Peru, que durou seis meses, continuou seu trabalho como jornalista e escritor, escrevendo uma coluna de opinião no jornal "Expreso", que, assim como os outros meios de comunicação, já havia sido confiscado pela ditadura militar presidida pelo general Juan Velasco Alvarado, de caráter esquerdista. Benedetti será obrigado a deixar o país ao começar a segunda fase da ditadura peruana, em agosto de 1975, um segundo golpe de Estado que derrubou Alvarado do poder. Benedetti narra com humor o drama vivido na Central de Polícia onde recebeu o "gentil convite" para que deixasse o país imediatamente. Entre as alternativas dadas pela polícia limenha - ser deixado na fronteira com o Equador ou tomar um voo de volta para Buenos Aires, o escritor optou por retornar à cidade onde havia sido ameaçado de morte pela Aliança Anticomunista Argentina: "Pensei rapidamente, e não me seduziu a ideia de que um veículo militar me deixasse, de madrugada, na fronteira de um país que então não conhecia, de modo que respondi: 'Buenos Aires. No Equador nunca estive" (Benedetti, 2011, p.20).

Para a ditadura uruguaia, 1975 foi o "Ano da Orientalidade". Enquanto Mario Benedetti passava seus dias de exilado em um pequeno apartamento no bairro de Miraflores, seu país celebrava a "unidade nacional" em diversos eventos públicos, como o "Primeiro Festival Folclórico Oriental de Canções para minha Pátria”, realizado no mês de março. Ou, no dia 23 de maio, o ato de repatriação dos restos mortais do coronel Lorenzo Latorre (1844-1916), Presidente de fato do Uruguai entre 1876 e 1879. O Governo impôs a censura prévia ao carnaval e normas de vestimenta e de asseio aos alunos e funcionários das escolas públicas. Dissolveu a Federação Nacional de Professores de Ensino Secundário, acusada de receber ajuda financeira de grupos de esquerda. Essas e outras medidas tinham como objetivo impor a ideologia nacionalista e as diretrizes das Forças Armadas diretamente sobre os meios de educação, de comunicação e de cultura.

A face mais obscura da ditadura, porém, é conhecida não pelos $69 \%$ da população que uma pesquisa da empresa Gallup informou apoiar a gestão governamental, mas pelos militantes das organizações de esquerda. Em outubro de 1975, começou uma operação contra o Partido Comunista durante a qual "centenas de militantes são detidos e torturados" (Martínez, 2008, p.57). Seguia aumentando o número de mortos e de desaparecidos.

A partir de 1976, Benedetti passará uma longa temporada exilado em Cuba, até o final de 1979. Ele voltou a trabalhar na organização Casa de las Américas e estabeleceu fortes 
vínculos com os outros exilados - chilenos, argentinos, nicaraguenses. Já com alguns dirigentes cubanos, Benedetti manteve relações conflituosas, por discordar de certos critérios políticos e culturais adotados pelo governo.

No Uruguai, prossegue a repressão contra os comunistas. "Vinte e três militantes são presos entre dezembro de 1975 e janeiro de 1976. Apenas doze sobreviverão" (Martínez, 2008, p.63). No dia 2 de janeiro, os militares informam terem destruído toda estrutura de propaganda e de financiamento do Partido Comunista. No dia 12 de maio de 1976, o Presidente Bordaberry anuncia que não haverá eleições, pois a "nova legitimidade", surgida a partir da dissolução do Congresso em 1973, não tem prazo para acabar. Os militares apoiam a declaração presidencial e confirmam que as atividades partidárias permanecerão proibidas. É um ano chave para a ditadura. Por um lado, porque uma vez suspensas as eleições por tempo indeterminado, em meio a uma escalada da ação repressiva, fica descartada qualquer possibilidade de abertura do regime. Por outro lado, as tensões entre o Presidente Bordaberry e os Comandantes das Forças Armadas, em virtude dos diferentes planos políticos em jogo, levam à destituição do Presidente, no dia 12 de junho. Em seguida, são promulgados dois Atos Institucionais (AI-1 e AI-2) pelo novo Presidente, Alberto Demichelli. O AI-1 suspende a convocação para as eleições nacionais. O AI-2 cria o "Conselho da Nação", entidade que passaria a designar o Presidente da República. Na prática, a decisão caberia à Junta de Oficiais generais das três armas.

A fundação da "nova ordem" se consolida em setembro de 1976, com o decreto do Ato Institucional $\mathrm{n}^{\circ} 4$ que "suspende os direitos políticos por 15 anos dos candidatos a cargos eletivos das organizações marxistas ou pró-marxistas declaradas ilegais, de todos os titulares e suplentes que ocuparam cargos parlamentares nas Câmaras eleitas em 1966 e 1971 e dos membros das Direções dos partidos políticos” (Martínez, 2008, p.80).

1976 foi também o ano em que começaram a aparecer cadáveres mutilados na costa uruguaia. A Marinha uruguaia afirmou, em certas ocasiões, tratar-se de chineses ou de nacionais de outro país asiático, tripulantes de navios de pesca. Alguns corpos apareciam com as mãos atadas e com sinais evidentes de tortura. Eram vítimas da ditadura argentina, durante o chamado "Processo de Reorganização Nacional" (1983-1976). Os opositores do regime eram lançados ao mar de aviões militares. Em agosto do mesmo ano, em Buenos Aires, foram sequestrados o jornalista argentino Marcelo Gelman e sua esposa María Irureta, que tinha apenas 19 anos e estava grávida. Gelman foi assassinado ainda em Buenos Aires. Já sua mulher foi levada para Montevidéu e mantida presa até dar a luz, em novembro, a uma menina. A mãe foi morta. Seu corpo até hoje está desaparecido. A filha foi entregue ilegalmente à família de um policial e só veio a descobrir sua verdadeira identidade no ano 2000. É um dos casos mais célebres de vítimas da ditadura, em função da sentença promulgada pela Corte Interamericana de Direitos Humanos, em 2011, pela qual condenou o Estado uruguaio pelo desaparecimento de Maria Irureta e pela supressão da identidade de sua filha nascida em cativeiro. Em março de 2012, o Presidente José Mujica reconheceu a "responsabilidade jurídica" e "ética" do Estado pelos fatos.

A reformulação do Estado se aprofunda em 1977, quando a ditadura: 1) decreta o fim da estabilidade dos funcionários públicos, através do Ato Institucional nº 7 , e 2) "reestrutura a administração da Justiça", por meio do Ato Institucional n 8. No primeiro caso, a 
consequência é a "depuração sistemática da administração pública: a ditadura expulsa os funcionários que não podem provar sua adesão ao regime, ou um passado ideológico em branco" (Martínez, 2008, p.87). O AI-8 suprime o Poder Judiciário: as resoluções da Suprema Corte de Justiça, doravante denominada Corte de Justiça, "devem ser revisadas pelo Poder Executivo, que poderá modificá-las e até deixá-las sem efeito” (Martínez, 2008, p.94).

São medidas que tem como objetivo "forjar um novo conceito de legitimidade política" (Caetano, Rilla, 2011, p.67), amparado numa "aceitação pacífica" do regime por uma população cuja maioria é "apolítica”, segundo pesquisa da empresa Gallup (Caetano, Rilla, 2011, p.67). Para o Presidente Aparício Méndez, os outros 37\% dos uruguaios eram formados por "comunistas, sediciosos e políticos que perderam seus cargos". Diz, ainda, que "os homens de bem, os trabalhadores, as forças vivas não falam de ditadura, não pensam em ditadura nem reclamam direitos humanos" (Martínez, 2008, p.92).

São essas as notícias que Mario Benedetti recebe de seu país estando exilado em Havana. Mesmo que ainda estivesse em sua querida Montevidéu, certamente não faria parte dos $63 \%$ que aceitavam pacificamente o regime. Benedetti pertencia à "outra região do Uruguai” (Campanella, 2008, p.172), aquela do exílio político. Os contos de Con y sin nostalgia, de 1977, livro que abordaremos a seguir, têm como tema o exílio. Porém, como disse Benedetti, os relatos são como "pontes" que conduzem ao "outro Uruguai”, o país da ditadura.

Vejamos que país é esse que ressurge nas páginas da ficção.

\section{TORTURADORES E TORTURADOS}

Dedicaremos esta seção do artigo à análise de alguns contos do livro Con y sin nostalgia, publicado por Benedetti em 1977, quatro anos após a instalação da ditadura no Uruguai.

À semelhança do país real, no Uruguai de Con y sin nostalgia também as pessoas, os grupos políticos e os sindicatos passaram à ilegalidade. Mas no primeiro conto do livro, intitulado Los astros y vos, a ficção serve para comunicar ao leitor, mais que um dado político, um grande drama histórico-social, caracterizado pelo fato, aparentemente absurdo, de haver "bairros e povoados e vilas que se tornaram clandestinos" (Benedetti, 2010, p.275). O autor trata de expressar, na verdade, o absurdo - em toda sua extensão e profundidade - da repressão da ditadura sobre toda uma sociedade. Sociedade esta que, após o golpe de 1973, transforma radicalmente a vida do comissário de polícia Oliva, de uma cidadezinha ordinária e sem delinquência - Rosales -, na qual não faria diferença ser policial, pedreiro ou bancário... Até o momento em que se instala a ditadura. A primeira mudança é externa: Oliva, que "antes não usava quase nunca o uniforme", agora passa a andar o tempo inteiro uniformizado. E assume uma atitude de "rigidez e de autoritarismo" jamais vista pelos moradores da cidade.

No pequeno município há somente um jornal de destaque, La Espina de Rosales, periódico que publica a "coluna de horóscopo" do jornalista Arroyo, um artifício para veicular diariamente "referências muito concretas e muito fáceis de comprovar sobre distintas possibilidades de um futuro presumivelmente próximo" (Benedetti, 2010, p.275). A radical transformação do chefe de polícia é notada pelo jornalista, cujas colunas "começaram a expressar um prognóstico sombrio para o futuro" da pequena cidade. 
Por vezes, a realidade política e a representação ficcional tornam-se indistinguíveis. Quando, por exemplo, os estudantes do liceu local decidem fazer uma passeata de protesto "contra o golpe, contra a dissolução do parlamento, contra o fechamento dos sindicatos, contra as torturas", a população interiorana assiste incrédula a detenção dos manifestantes e custa a acreditar que alguns deles estão sendo torturados (Benedetti, 2010, p.276). As previsões de Arroyo ficam cada vez mais sinistras, à medida que a repressão conhece uma escalada na cidade. O único advogado disponível procura o juiz local a fim de interceder em nome dos presos políticos. Descobre que o próprio juiz encontra-se encarcerado. Recorre, então, às autoridades da capital, e acaba caindo numa das celas de um presídio de Montevidéu. Arroyo reage em sua coluna: "Se aproxima a hora do absurdo. O ódio começará a penetrar nas almas boas" (Benedetti, 2010, p.277).

Esse ódio alcança seu auge quando, certa noite, Oliva, bêbado e bem escoltado, irrompe no Centro Social de Rosales durante um baile e obriga uma grávida a dançar com ele "sem interrupção três tangos, dois boleros e uma rumba", provocando um aborto horas depois. A repressão condena à morte até mesmo os que ainda estão por nascer. Diante do medo da população e da conivência das autoridades locais e federais com relação às violações cometidas por Oliva, Arroyo começa uma campanha contra o policial, publicando uma série de prognósticos tenebrosos, que anunciam o fim do "aprendiz de déspota" que inferniza a vida dos cidadãos do povoado.

O conto chega ao seu ponto culminante durante o enfrentamento entre o jornalista e o chefe da polícia. Este quer obrigar aquele a escrever uma previsão favorável para seu futuro. Arroyo se recusa a obedecer à ordem do delegado, argumentando, como bom "astrólogo", que os astros dizem o contrário. No final, o que o leitor descobre é que o destino de Oliva não está escrito nas estrelas, tampouco nas linhas de um jornal, mas na trajetória de uma bala disparada por Arroyo à queima-roupa contra o policial.

O segundo relato, Escuchar a Mozart, já não trata do conflito entre agentes da ditadura e os seus opositores, mas dos antagonismos entre militares que integram as forças repressoras, e da desordem mental que se apossa de um deles, o capitão Montes, cuja rotina consiste em receber presos "já bastante maltratados" e arrebentá-los "um pouquinho mais" durante sessões de tortura. Benedetti descreve neste conto a "clandestinidade" dos repressores, que perseguem aqueles que se encontram fora da legalidade, ao custo de viver - angustiados fora da moralidade ou fundamentando suas ações em uma moral pervertida pela ideia de que "os fins justificam os meios". Montes oculta da esposa e do filho as violências que comete em nome do "espírito de corpo" e pelo medo de sofrer sanções ou rebaixamento caso recuse a aplicar a tortura contra os prisioneiros políticos. É um militar que sofre com sua "consciência pesada”, que tenta, em vão, aliviar ouvindo as sinfonias de Mozart e bebendo uísque. O que mais teme é que sua família descubra a "escandalosamente suja verdade" de seu trabalho. E quando é confrontado com essa verdade pelas perguntas diretas de seu filho de apenas oito anos, a relação pai-filho degenera-se, transformando-se em mais uma sessão de tortura.

A ficção de Benedetti demarca uma fronteira nítida entre a "esquerda uruguaia" e os agentes da "duríssima repressão". No conto La colección, um grupo pertencente a um setor indeterminado da esquerda invade um apartamento de uma família de classe média em busca da coleção de armas do dono da casa. Em contraste com a violência física e psicológica 
empregada pela polícia e pelas Forças Armadas, os invasores tratam seus reféns - os três filhos do casal que está viajando - de maneira gentil enquanto vasculham a residência em busca do armamento. Depois que os guerrilheiros deixam claro que não empregarão nenhuma violência contra as crianças para forçar-lhes a revelar o esconderijo da coleção, passam a contar com a simpatia e com a colaboração da filha mais velha, uma jovem de dezessete anos, que discorda do conservadorismo político do pai, e decide indicar o local onde estão guardadas as armas.

Os contos de Con y sin nostalgia exibem, de maneira evidente, a característica essencial da ficção: ser expressão da insatisfação dos homens com o seu destino. Para Vargas Llosa (2004, p.16), a ficção "é escrita e lida para que os seres humanos tenham as vidas que não se resignam a não ter. No embrião de todo romance ferve um inconformismo, pulsa um desejo insatisfeito". Nos relatos que analisamos acima, Benedetti representa muito bem a rebeldia e os anseios de uma sociedade que experimenta um alto grau de repressão política, social e cultural.

No conto Sobre el éxodo, Benedetti aventura-se no campo do "realismo mágico" e apresenta um país - "paisito" - imerso em uma "atmosfera irrespirável” gerada por uma "repressão monstruosa” que obriga a população a deixar o país até só restarem os presos e o presidente da República. Os militares também emigram quando passam a ficar "desocupados" devido à escassez de gente para submeter à tortura. Os detentos não demoram muito a perceber que ninguém mais se interpõe entre eles e a sua liberdade: em poucas horas caminham do presídio até o palácio do governo onde encontram o chefe de Estado, ao qual "solicitam" o "favor" de dar um tiro na própria cabeça. O som do disparo é o sinal que informa aos exilados que eles já podem regressar.

Benedetti escreve ficção para compensar as vítimas da repressão da sua condição de exilados, de presos, de torturados. O escritor soma-se ao grupo de intelectuais latino-americanos que defendem a perspectiva do "exílio combatente", que "consiste em apresentar este sob uma visão positiva, que supere os pessimismos, às vezes inevitáveis, mas sempre estéreis" (Bay, 2000, p.41).

Os personagens de Benedetti sacrificam a vida pessoal, abandonando o conforto do lar e a segurança de um bom casamento, como faz, por exemplo, o protagonista do conto Gracias, vientre leal, para participar de ações armadas contra o governo. Seu compromisso político contrasta flagrantemente com o apego da esposa à sua vida privada. Para ela o que importa é que ambos "estejam bem" em seu mundo particular, pois ela não é "suficientemente generosa” para antepor o destino do país ao destino do casal. O marido, sim, é generoso o suficiente para separar-se do "ventre leal" da mulher amada.

Altruísta é também Vicente, o "pequeno burguês" que, por lealdade aos companheiros, suporta a tortura e encara a morte como forma de sabotar os desígnios de seus torturadores porque morto não arrancaram nenhum nome dele (no conto Pequebú).

Nem todos os personagens do livro, porém, surgem como "heróis positivos". Alguns exibem apenas suas cicatrizes e amarguras no exílio, como o casal de militantes que divide um pequeno quarto de hotel, em Paris (El hotelito de la rue Blomet). É o exílio "não combativo", o "exílio como frustração", segundo a expressão de José Juan Pérez (2009, p.107). Os diálogos entre os amantes revelam que ambos foram "destroçados em suas vidas afetivas" pelas ações da ditadura: "Existe um sentimento de fracasso por sua própria ruptura motivado pela repressão política sofrida no Uruguai” (Pérez, 2009, p.109). 
E no último e mais extenso conto do livro - La vecina orilla - Benedetti recria "o asfixiante ambiente de Buenos Aires entre 1974-76, que ele vivera em todos os detalhes: tiroteios, sequestros, Ford Falcon, solidariedade, milanesas, sorvete de doce de leite, moda $h i$ ppie" (Campanella, 2008, p.173). Aqui o protagonista é um "herói involuntário", um jovem estudante de 16 anos, que na sua turma era "o único exemplar de uma espécie em extinção: a dos que não amam nem o estudo, nem a política" (Benedetti, 2010, p.335). E justamente por tratar-se de um caso isolado, não pode escapar do ambiente de radicalismo ideológico e de repressão que o leva, sucessivamente, à cadeia, onde é brutalmente espancado, e ao exílio em Buenos Aires. E sofre tudo isso, a seu ver, não por convicção política, mas por "estupidez".

Para Carmen Bay, o final do conto conteria uma "convocação à luta contra as injustiças que se vivem no Uruguai e em tantos países da América Latina daqueles anos” (Bay, 2000, p.11). Mas antes de chegar a tal desfecho, Benedetti representa a perspectiva assombrada da realidade vista por um personagem "descomprometido", muito jovem e inexperiente. É evidente a "índole social" dos relatos, e sabemos de que lado está seu autor. Porém, o contista e novelista não pretende escrever panfletos políticos, e sim produzir relatos segundo princípios literários, artísticos, que considera válidos para sua época histórica.

O protagonista de La vecina orilla é uma criação baseada, em parte, em determinados princípios teóricos. O desafio do escritor é ser capaz de harmonizar suas convicções pessoais, sua experiência de vida e seus princípios artísticos na hora de expor suas representações da realidade na sua ficção. Em cada conto, em cada novela de Benedetti, o resultado dessa tarefa é distinto. Em outras palavras, há obras, e trechos de obras, em que as convicções pessoais, ideológicas, sobressaem em relação aos princípios literários que o próprio autor considera corretos seguir. Em outros casos, a biografia do escritor - seu apego à memória de determinadas experiências - interfere na fatura de personagens originais, conferindo-lhes um efeito de "cissiparidade" literária - o mesmo protagonista, a mesma psicologia, replica-se em diferentes relatos - o que dá um ar esquemático, às vezes manil queísta, a uma literatura que prega o aprofundamento psicológico e o abandono do manual.

Seja com maior ou menor qualidade artística, é inegável que a representação do real na ficção de Benedetti segue o compromisso, sobretudo no período da ditadura, de manter-se o mais próxima possível dos eventos políticos e sociais mais relevantes daquele período da história uruguaia, seguindo os princípios do estilo realista que abordamos na introdução deste artigo. Por "realidade" entenda-se a representação, sob a forma de ficção, de um determinado conjunto de temas sociais de grande repercussão política e social - a repressão, a tortura, o exílio-, de modo que, por vezes, a ficção parece ser uma extensão dos "acontecimentos" sobre os quais tomamos conhecimento através dos jornais, dos livros de história, da televisão. Lembrando que tanto a ficção quanto o noticiário, ou a história, narram acontecimentos segundo determinados fundamentos, alguns diriam "limites", teóricos e técnicos, e imbuídos de valores. Dessa forma, a ficção de Benedetti não se parece em nada com a narrativa oficial da história uruguaia, expressa nos discursos das autoridades, na imprensa colaboracionista ou nos livros escolares. Para se chegar à conclusão de que a ficção de Benedetti tem a "realidade" como "eixo", é preciso comparar sua narrativa com outras narrativas semelhantes, que funcionam como referências. A comunicação com o 
leitor só será "efetiva" se este compartilhar com o autor alguns desses referenciais. Caso contrário, não há porque pressupor que a ficção parecerá ancorada na realidade, que é sempre a realidade do leitor.

Consideremos o tema da tortura, por exemplo. No conto Escuchar a Mozart, Benedetti representa a um torturador em conflito com sua consciência e que acaba, no auge da perturbação mental, voltando-se contra seu próprio filho. O que, neste conto em particular, sustentaria o argumento de que o eixo da ficção é o real? Não é o "acontecimento", ou seja, o fato de um militar que maltrata presos políticos matar o próprio filho de oito anos sob tortura. Ainda que o relato fosse baseado em um fato real - o assassinato de uma criança pelo pai militar e torturador- a questão de se o motivo do crime fora a insanidade paterna causada pelas ações cometidas contra presos políticos permaneceria no campo da especulação.

Comparemos a especulação com um fato histórico. Em maio de 1980, o fotógrafo e soldado Hugo García Rivas desertou do Exército uruguaio e fugiu para o Brasil. Rivas deu um testemunho detalhado "sobre o funcionamento dos órgãos de repressão. Sequestros, assassinatos, cursos de inteligência e tortura, corrupção e a denúncia com nome, sobrenome e fotos de uns 60 torturadores" (Martínez, 2008, p.137). O soldado também publicou uma "carta de um ex-torturador" em que se dirige aos seus "companheiros" rogando-lhes que reflitam sobre as funções que cumprem e que cheguem à mesma conclusão ao qual ele chegara: a tortura é um ato indigno, que deve ser repudiado e abandonado em nome da salvação da personalidade, da alma e da pátria.

Se o leitor compartilha com o escritor esse tipo de conhecimento, além dos valores a ele associados, então a "representação do real" e a realidade do leitor estarão sob o mesmo eixo, independentemente do relato em si.

\section{DOS ESCOMBROS À RECONSTRUÇÃO.}

Encerraremos o artigo comentando a última obra de ficção que Benedetti publicou antes do término do período autoritário, Primavera con una esquina rota, de 1982.

Quando publica essa novela, Benedetti está vivendo com a esposa, Luz, em Palma de Mallorca. Eles chegaram à Espanha em 1980, quando o Uruguai já entrara em um período de transição, no qual a ditadura decide dar início a um processo de "prudente abertura" (Caetano, Rilla, 2011, p. 69). O projeto dos militares, a princípio, era o de "fundamentar a tutela das Forças Armadas sobre o sistema político” (Caetano, Rilla, 2011, p.70). Com esse objetivo, a fins de 1978, a Corte Eleitoral elaborou um projeto de estatuto para os partidos políticos, apresentado pelo Governo no dia 6 de fevereiro de 1979. O documento "proíbe grupos que tenham vínculo com ideologias de partidos estrangeiros ou com outros Estados” (Martínez, 2008, p.119). Durante esse último ano, a Junta de Oficiais Generais delibera sobre o projeto constitucional que seria submetido à consulta popular no dia 30 de novembro de 1980. Em termos de organização institucional, o texto previa que as Forças Armadas assumiam competência direta em matéria de "segurança nacional". Institucionalizava, então, o Conselho de Segurança Nacional e criava um Tribunal de Controle Político que poderia anular eleições, dissolver partidos políticos e "até destituir autoridades partidárias" 
(Caetano, Rilla, 2011, p.75). Apesar da publicidade do Governo através do rádio e da televisão a favor da aprovação do projeto, 57,9\% dos eleitores votaram contra a reforma constitucional. A partir dessa data, os "militares começaram a perder a iniciativa política" e acabaram recorrendo à mediação partidária para pôr em andamento um novo processo que almejava o "consenso da sociedade civil" (Caetano, Rilla, 2011, p.94).

Nesse contexto, 1982 foi um ano chave, pois boa parte da oposição política foi legalizada. Além disso, a classe empresarial questionou diretamente a política econômica da ditadura e os movimentos sindical e estudantil começaram a dar sinais de reativação. Também alguns setores da esquerda iniciaram gestões em favor da legalização das suas atividades políticas. Governo e partidos passaram a trabalhar com a perspectiva da realização de eleições gerais em 1984.

A atmosfera de lenta abertura política está presente em Primavera con una esquina rota sob a forma de um balanço geral do período da ditadura sob o ponto de vista de personagens que sofreram e ainda sofrem as consequências da repressão: Santiago, o preso político; Graciela, sua mulher, que deve suportar a separação no exílio, e lidar com a filha do casal, de 9 anos, Beatriz, traumatizada pela prisão do pai e pela fragmentação da família; Don Rafael, pai de Santiago, outro exilado, professor, afligido pelo encarceramento do filho e pela percepção de que a nora cada dia se distancia mais do marido; Rolando, antigo amigo de Santiago, convertido em amante de Graciela; e Benedetti, o próprio autor, que intercala os capítulos da ficção com seus testemunhos, denominados "Exílios”, em que narra suas próprias experiências como expatriado.

Desse núcleo autobiográfico, devemos destacar o último texto, intitulado Los orgullosos de Alamar. Benedetti viveu dois anos em Alamar, região localizada a uns quinze quilômetros de Havana. Naquela zona, o governo cubano cedia gratuitamente apartamentos mobiliados para exilados latinoamericanos, daí sua grande concentração na localidade. Benedetti já não se encontrava em Alamar no dia 30 de novembro de 1980, na data da realização do plebiscito constitucional, que o escritor define como "rasteira que a ditadura passou em si mesma". Já morava na Espanha então. Mas lembrou-se de Alamar no dia da vitória do "Não" no referendo popular porque "havia sido bom celebrar ali a incrível goleada" (Benedetti, 2011, p.160). Além disso, teve oportunidade, ao voltar a Cuba, em janeiro de 1981, de ouvir de outro uruguaio a descrição da grande festa que os exilados de Alamar fizeram, da noite até o nascer do Sol, comemorando a derrota do projeto militar no Uruguai.

Ao dividir o relato em diferentes núcleos, e reservar um espaço separado para a autobiografia de exilado, Benedetti escreveu uma das obras mais bem sucedidas desse período e das mais representativas de uma geração. Em contraste direto com o próprio autor, os protagonistas ganham mais vivacidade e verossimilhança. Os diferentes pontos de vista dão a sensação ao leitor de acesso a um panorama subjetivo e ao mesmo tempo global, porque construído por diferentes subjetividades. O espaço habitado pelos exilados, suas emoções e respectivas visões da realidade e da história, são contrapostos ao espaço da cela ocupada por Santiago e à sua perspectiva de, em breve, obter a liberdade e poder reencontrar-se com a família e os amigos. O choque entre o tempo objetivo da narrativa - que cria a expectativa da restauração dos laços afetivos - e o tempo subjetivo - que evidencia rupturas psicológicas irreparáveis - retém o interesse do leitor nos destinos desses "vencidos" que se negam a aceitar "esta morte que parece sem volta" (Benedetti, 2011, p. 97). 
Ao final, os vencidos aceitam a derrota. A realidade se impõe. Rolando, ao relembrar as discussões políticas com os companheiros, retrata um grupo de idealistas ingênuos que, ao se levantarem em armas contra o governo, acabaram presos ou mortos ou exilados. Don Rafael, refletindo sobre a situação do filho, só pode lamentar o fracasso de uma luta que o condenou à prisão. Santiago, durante os longos anos de cárcere, "amadurece", passa a conhecer seus "próprios limites, debilidades e forças" e abandona as "ilusões a respeito de objetivos que jamais poderia alcançar". Limita-se a desejar "o que algum dia pode estar ao alcance”. E o próprio Benedetti satisfaz-se em celebrar, no exílio, não a revolução com a qual ele e seus personagens sonharam, mas o retorno à democracia no ritmo permitido pelas Forças Armadas.

\section{REFERENNCIAS}

ACHUGAR, Hugo. Paisajes y escenarios de la vida privada - literatura uruguaya entre 1920 y 1990. In: BARRAN, Pedro; CAETANO, Gerardo; PORZECANSKI, Teresa (Dir.). Historias de la vida privada en el Uruguay - Individuo y soledades 1920-1990. Montevidéu: Taurus, 2004.

BAY, Carmen Alemany. Mario Benedetti, Madri: Eneida, 2000.

BENEDETTI, Mario. Cuentos completos. Montevidéu: Seix Barral, 2010.

BENEDETTI, Mario. Primavera con una esquina rota. Montevidéu: Seix Barral, 2011.

CAETANO, Gerardo; RILLA, José. Breve Historia de la Dictadura. Montevidéu: Banda Oriental, 2011.

CAMPANELLA, Hortensia. Mario Benedetti: un mito discretísimo. Montevidéu: Seix Barral, 2008.

GREINER-MAI, Herbert. Literatura General y Comparada. Madri: Akal, 2006.

HABERKORN, Leonardo: La terquedad del poeta, in: Crónicas de sangre, sudor y lágrimas. Montevidéu: Fin de Siglo, 2011.

LAGO, Sylvia. La poesía como iluminación. Montevidéu: Brecha, 1986 apud REIN, 1996.

MARTÍNEZ, Virgínia. Tiempos de Dictadura (1973-1985). Montevidéu: Banda Oriental, 2008.

PÉREZ, José Juan. El exílio como frustración en tres cuentos de Mario Benedetti. Cuadernos del Ateneo de la Laguna, Tenerife, n.28, p. 107-112, 2009.

RAVIOLO, Herbert; ROCCA, Pablo (Org.). Historia de la Literatura Uruguaya Contemporanea. Montevidéu: Banda Oriental,1996. 
REIN, Mercedes: Mario Benedetti y el proyecto cultural de la generación del “45”. In: RAVIOLO, Herbert; ROCCA, Pablo (Org.). Historia de la Literatura Uruguaya Contemporanea. Montevidéu: Banda Oriental, 1996.

VARGAS LLOSA, Mario: A Verdade das Mentiras. São Paulo: Arx, 2004.

VALÉRY, Paul. De Poe a Mallarmé - Ensayos de poética y estética. Buenos Aires: El cuenco de plata, 2010. 